\title{
Truth telling in Foucault and Arendt: parrhesia, the pariah and academics in dark times
}

\author{
Maria Tamboukou \\ Centre for Narrative Research, School of Law and Social Sciences, University of East \\ London, London, UK
}

\begin{abstract}
In this paper, I consider the problem of truth telling through the notion of parrhesia as developed and explicated in Foucault's last lectures at the College de France (1982-1983 and 1983-1984) and the figure of the pariah that runs throughout Arendt's work. In tracing connections and tensions in the way the two thinkers explore questions and dilemmas around the courage to tell the truth in philosophy and politics, I look into the current climate within the UK academia, where there is a lot of ambivalence about whether people mean what they say or say what they mean anymore. In a Foucauldian mode of inquiry, I raise the question: what is the role of the academic when going through 'dark times', vis-à-vis questions of truth telling; what are the conditions of possibility for truth telling itself to be recognised as a question or a problem and how can we start mapping the effects of what we as academics do or refrain from doing?
\end{abstract}

Keywords: Arendt; academics in dark times; Foucault; parrhesia; pariah

'Just as it is philosophy's task to unite truth and freedom, so it is the equally herculean task of politics to bring freedom and justice together', ${ }^{1}$ Heinrich Blücher was writing to Jaspers, in September 1961 soon after he and Hannah Arendt had visited Karl and Gertrud Jaspers at their Basel home. ${ }^{2}$ Among the many things that he ]discusses in this letter, written in the wake of the construction of the Berlin wall, Blücher particularly refers to Jasper's book, The Idea of the University, which had just been translated in English (Jaspers 1961). In this book Jaspers considers the role of the academic and her/his relation to politics, a theme that Blücher was deeply interested in. Not having any formal academic title, Blücher was a highly esteemed philosophy teacher at the New English School for Social Research and later at Bard College; 'the education of the young' in truth and freedom was at the heart of his teaching. As he was noting at the end of his letter to Jaspers: 'They [the young] are asking for the truth. If we respond correctly, can't we perhaps interest them in freedom?'3 Blücher's epistolary question has been at the heart of philosophical debates and literary texts since the antiquity, but it is particularly crucial today when academic education is entering a regime of 'dark times'. How is it possible to think and act within 'dark times?' This is the central question that I address in this essay by looking into the politics and practices of truth telling through the Foucauldian notion of parrhesia and the Arendtian figure of the pariah. 
Parrhesia preoccupied Michel Foucault at the end of his life as a critical notion in a genealogy of the relationship between philosophy and politics (Foucault 2008, 2009). The latter has also been a constant preoccupation for Arendt, particularly through her experience of how the German academic circles she was part of, reacted or rather did not react to the rise of Nazism in Germany. Indeed, shortly before she left Germany in 1933, Arendt was terrified not by what the Nazis were doing, but by the way the German intellectual circles did not respond to what was happening, lost as they were in their philosophical reflections. As she boldly put it in a 1964 interview with Günter Gauss, 'the problem, the personal problem was not what our enemies did but what our friends did' $(1994,11)$.

The essay is in four parts. In the first section, I explore philosophical links and influences between Foucault and Arendt. Then in the second section, I discuss Foucault's elaboration of the notion of parrhesia, mainly drawing on his two last courses at the Collège de France in 1982-1983 and 1983-1984. The third section examines the figure of the pariah in Arendt's work, while in the final section I consider the role of the academic in 'dark times', in the context of practices of truth telling.

\section{Philosophical encounters}

While a number of scholars have already charted connections between Foucault and Arendt, ${ }^{4}$ to the best of my knowledge there is not a single reference to each other in the body of their own work, although they were both imbued with the French and German philosophical traditions and they had become philosophical celebrities in the USA. It was probably too late for Arendt to have noted Foucault's work, but Foucault must have surely encountered Arendt's oeuvre. Having myself delved in both philosophers' work for the last 15 years I have found striking interfaces not only in the intellectual founding of their theorisation, but more importantly in lines of thought that I will argue considerably criss-cross the multilevelled and often conflicting planes of their political philosophy. In thus following lines of already charted connections between Foucault and Arendt, in this essay I consider a genealogy of philosophical figures that were influential in the development of their political philosophy, albeit not always explicitly so, namely Heidegger, Kant and [Plato's] Socrates. In doing this I particularly focus on Heidegger's notion of truth, Kant's idea of the revolution and Plato's preoccupation with the precarious relationship between philosophy and politics. These themes have been central in both thinkers' writings on the relationship between truth and politics, which underpins both Foucault's engagement with the notion of parrhesia and Arendt's configuration of the pariah.

\subsection{Heidegger's shadow}

In his very last interview, on the occasion of the publication of the second and third volumes of The History of Sexuality and shortly before his premature death Foucault pithily summarised his intellectual relationship with Martin Heidegger:

For me Heidegger has always been the essential philosopher ... My entire philosophical development was determined by my reading of Heidegger ... But I have never written anything on Heidegger ... I think it is important to have a small number of 
authors with whom one thinks, with whom one works, but about whom one does not write. (Foucault 1990, 250)

Heidegger was of course a fundamental philosophical encounter for Arendt: he was the young inspired professor whose lectures and seminars at the University of Marburg she joined in 1924, when she was only 18 years old, a philosopher she loved and was disappointed by and a constant presence/absence till the end of her life. ${ }^{5}$ Unlike Foucault, Arendt wrote a number of essays on Heidegger, drew on his work but also seriously criticised and challenged it particularly in her last unfinished philosophical work, The Life of the Mind (1981). As poetically put by Arendt herself in a letter to Heidegger that was never sent, ${ }^{6}$ he was the man 'to whom I remained faithful and unfaithful, and both in love' (Ettinger 1995, 1).

Clearly, I could not possibly discuss here Heidegger's influence on both thinkers in its entirety. ${ }^{7}$ As already noted, I will focus instead on the Heideggerian conceptualisation of truth, which I think is crucial in how Foucault and Arendt theorise and discuss the relationship between truth and politics. Firstly elaborated in his 1930 Freiburg lecture on 'The Essence of Truth' (1998/1943), Heidegger's approach to truth goes back to its Greek roots, where the notion of $\alpha \lambda \eta \operatorname{hel\alpha }$ [aletheia] is conceptualised as unhiddenness rather than correspondence. As Heidegger $(2002,8)$ configures it:

Initially, the meaning of the Greek word for truth, unhiddenness, has nothing to do with assertion and that factual contexture in terms of which the essence of truth is usually explained, i.e. correctness and correspondence. To be hidden and unhidden means something quite different to correspondence, measuring up, directedness towards ... Truth as unhiddenness and truth as correctness are quite different things; they arise from quite different fundamental experiences and cannot at all be equated.

It is this Heideggerian conceptualisation of truth as 'unhiddenness', revealing something that it is concealed, forgotten or distorted that underlies Foucault's genealogical investigation in the notion of parrhesia through a number of philosophical and literary texts in classical antiquity and beyond. In his 1982-1983 lectures at the College de France, Foucault (2008) investigates a number of texts, but given the restrictions and particular focus of this essay, in the following section I will discuss his engagement with Socrates' Apologia, which constitutes according to his analysis a philosophical parrhesiastic moment par excellence. Interestingly enough, Socrates' Apologia has also become a reference point for Arendt's preoccupation with questions of truth and the precarious relationship between philosophy, truth and politics (Arendt 2006).

\subsection{Kant and the idea of the revolution}

Kant has clearly been an influential philosophical presence for both Foucault and Arendt. Foucault's secondary doctoral thesis was a translation of, as well as an introduction to Kant's anthropology. ${ }^{8}$ Moreover during his penultimum course at the Collège de France in 1982-1983, Foucault ${ }^{9}$ discussed at length Kant's influential essay, Was ist Aufklärung, by linking it to his thoughts on the revolution as presented in The Contest of the Faculties and in Perpetual Peace. ${ }^{10}$ In concluding the first part of his lecture on 5 January 1983, Foucault would note: 
it seems to me that these two questions - 'What is Aufklärung' and 'What is the Revolution' - which are the two forms in which Kant poses the question of his own present reality, have continued to haunt, if not all of modern philosophy since the nineteenth century, then at least a large part of this philosophy. (Foucault 2010, 20)

In Foucault's view, Kant's aforementioned essays are crucial in considering the philosopher's relationship to politics, a theme with which he ultimately concluded his last lectures at the Collège de France in 1983-1984 (Foucault 2011).

Kant has been a critical philosopher in Arendt's late philosophical work (1982) and particularly in the development of judgement as a faculty of the mind that would become the third part of The Life of the Mind (Arendt 1981), had she not died unexpectedly. Nevertheless Kant's Critique of Aesthetic Judgement (1952) is Arendt's philosophical frame of reference in what for her was the most political function of the mind, namely judgement. As she was writing to Jaspers on 29 November 1964, she could discern 'a possible conceptual structure for history and political science' in the Critique of Judgement that she wanted to further discuss with him. (Arendt and Jaspers 1993, 576) In the context of her engagement with the third critique, which she considered as the site par excellence of Kant's political philosophy, Arendt has also discussed Kant's influential essay on the French revolution. ${ }^{11}$ Here again the relationship between philosophy, truth and politics is at the centre of the discussion.

\subsection{Socrates' death: philosophy and politics}

On 22 February 1984, this is how Foucault concluded his eighth lecture at the Collège de France: 'As a philosophy professor one really must have lectured on Socrates and the death of Socrates at least once in one's life. It's done. Salvate animam meam' (Foucault 2011, 153). But did Foucault really need to pay his debt to Socrates by lecturing on the death of the philosopher - despite the moving connotations surrounding this concluding sentence in the light of his actual death, only four months later - or is there something more in the philosopher's death that makes the necessity for a course on it a conditio sine-qua-non of philosophical teaching? According to Arendt, Socrates' death colours and underpins the philosopher's departure from the world in the famous allegory of the cave in The Republic; it therefore marks a deep rupture between philosophy and politics that will only be recuperated with Karl Marx's advent in the philosophical scene:

The beginning was made when in The Republic's allegory of the cave, Plato described the sphere of human affairs - all that belongs to the living together of men in a common world - in terms of darkness, confusion and deception which those aspiring to true being must turn away from and abandon if they want to discover the clear sky of eternal ideas. The end came with Marx's declaration that philosophy and its truth are located not outside the affairs of men and their common world but precisely in them, and can be 'realized' only in the sphere of living together, which he called 'society' through the emergence of 'socialized men'. $(2006,17)$

Still, what is it about philosophical life that makes it incompatible with politics and even if they can and should coexist - as Marx ardently argued - how is their coexistence to be understood and maintained? The philosopher's death has further been linked to what Foucault discussed and theorised as 'the courage of truth' (2009) 
manifested in extremely risky situations and defying any kinds of risk, including death. In this light, Socrates' death is for Foucault a parrhesiastic act par excellence but instead of closing down possibilities of a relationship between politics and philosophy, it actually creates conditions for a reconfiguration of this relationship; this however, comes hand in hand with a new conceptualisation of politics and philosophy, as entities now illuminated by the philosopher's death. So how should these entities be perceived and how is the figure of the philosopher itself changed? This is where the notion of parrhesia and the figure of the pariah enter the cycle of the discussion.

\section{Parrhesia: modalities of truth telling}

Parrhesia is a Greek word and Foucault devotes a great deal of his lectures in 1982 to locate its roots, etymology and emergence in the ancient Greek literature. Since there is no space in this essay for philological details or a full genealogy of the concept ${ }^{12}$ I will rather consider two texts that become important for Foucault's discussion: Euripides' tragedy Ion and Socrates' Apologia.

In looking into a classical text of ancient Greek tragedy, Euripides' Ion, Foucault presents and discusses the notion of the parrhesia and its significance in the political technologies of the individual. There are many characters in this tragedy, but only two parrhesiastic roles according to Foucault: Kreusa the Athenian princess, who visits the oracle of Delphi to confront Apollo, and Ion her illegal son with the Delphic god. As a central character of the play, Ion is a young man, who serves the Delphic temple completely unaware of his origins. ${ }^{13}$ The tragedy revolves around the need for truth to be disclosed, while Delphi becomes the chronotope par excellence for such truth seeking and disclosure: Kreusa demands from Apollo the truth about the fate of their son; her parrhesiastic moment is a private one, configured within the restrictions and limitations of her gendered role. Ion wants the truth about his mother because without knowing his origins, he will never have parrhesia, the freedom to speak the truth, which is an essential precondition for going into politics and excel in it. What therefore lies at the heart of this play is the recurrence of parrhesiastic moments and practices, risky situations wherein truth is being sought, negotiated, granted or denied. As Foucault pithily puts it: 'Ion is entirely devoted to the problem of parrhesia since it pursues the question: who has the right, the duty, and the courage to speak the truth?' $(2001,27)$.

Foucault actually devotes five lectures, in January 1983 in exploring the parrhesiastic questions emerging in Euripides' Ion. ${ }^{14}$ Since it is in the parrhesiastic act that an individual assumes her right to speak, this practice becomes a quintessential precondition of freedom. In this analytical context, there are four essential themes constitutive of the parrhesiastic act: first is speaking the truth; second, having the courage to speak the truth in situations where there is a risk or danger for the truthteller; third, parrhesia is a form of criticism, either towards another or towards oneself and it should always come from below, from the powerless (or rather the less powerful, if we want to keep with the Foucauldian notion of power) and finally parrhesia, the telling of truth, is regarded as a duty and is further related to freedom. As Foucault pithily summarises it:

Parrhesia is a kind of verbal activity where the speaker has a specific relation to truth through frankness, a certain relationship to his own life through danger, a certain type 
of relation to himself or other people through criticism (self-criticism or criticising of other people), and a specific relation to moral law through freedom and duty. More precisely, parrhesia is a verbal activity in which a speaker expresses [his] personal relationship to truth, and risks his life because he recognises truthtelling as a duty to improve or help other people (as well as himself). In parrhesia, the speaker uses [his] freedom and chooses frankness instead of persuasion, truth instead of falsehood or silence, the risk of death instead of life and security, criticism instead of flattery, the moral duty instead of self-interest and moral apathy. (Foucault 2001, 19)

In thus acknowledging truth telling as both a necessary precondition of freedom and a considerable risk for the truth-teller, the Greeks had created a space for truth to be told by introducing what Foucault has defined as 'the parrhesiastic pact'. In this light, parrhesia sets up an ethical contract for both parties: the speaker will tell the truth without concealing anything and 'the prince' will listen to any harsh and/ or critical truth without punishing the truth-teller. In Foucault's conceptual configuration, this pact is actually situated at the heart of what he further defines as 'the parrhesiastic game', understandably so, since the notion of truth in Foucault's philosophical thought has always been a matter of 'truth games' (1988) rather than an absolute idea, form or state:

Thus the true game of parrhesia will be established on this kind of pact, which means that if the parrhesiast demonstrates his courage by telling the truth despite and regardless of everything, the person to whom this parrhesia is addressed will have to demonstrate his greatness of soul by accepting being told the truth. This kind of pact between the person who takes the risk of telling the truth and the person who agrees to listen to it, is at the heart of what could be called the parrhesiastic game. (Foucault $2011,12-3)$

This was the idea and practice of parrhesia in Euripides' tragedy Ion, where 'the prince' was Apollo, the Delphic god himself, and the parrhesiasts were a young man and an aristocratic woman, two characters unfolding different parrhesiastic roles that were mostly gendered configured and constrained. Of course Foucault's genealogical exploration of parrhesiastic acts in classical antiquity and beyond has actually revealed a series of breaches of this moral obligation in telling and listening to the truth, which reaches its culmination with Socrates' death. Indeed, the philosopher's death marks a turning point in the relationship between philosophy, truth and politics: the Athenian demos will not tolerate Socrates' parrhesiastic criticism and will give him a death sentence for endangering the city and corrupting the youth through his practices of truth telling. Moreover, although Socrates is offered the opportunity to escape, he decides to obey the laws and die as a consequence of his boldly manifested courage to tell the truth.

Thus, amongst the four figures in the modalities of truth telling that Foucault (2009) presents and discusses - the prophet, the sage, the teacher and the philosopher $^{15}$ - Socrates becomes the parrhesiast par excellence, through his decision to die for the sake of truth. ${ }^{16}$ What is indeed exceptional in the philosopher's parrhesia is the consistency between the philosopher's discourse and the way he conducts his life: $\log o s$ and bios are tightly interwoven and constituted through their interrelation. As Flynn $(1991,108)$ has succinctly noted, 'the Socratic parrhesia is properly philosophical in that it is concerned with practical reason (phronesis), with truth and with the soul'. In Flynn's configuration, these three components of 
the philosophical parrhesia further correspond to the three genealogical axes that Foucault pursued throughout his work: power, knowledge and the self $(107,108)$.

It is actually genealogical trails of truth telling and truth-seeking through a harmonious coexistence between logos and bios, discourse and life that Foucault traces in the rest of his 1984 lectures. His particular preoccupation with the Cynics in the rest of the course throws light on an obscure area of the philosophical discourse: the aesthetics of existence as a politics of 'true life' (bios alêthês). In explicating the notion of true life, bios alêthês, Foucault draws on his Heideggerian toolbox in terms of how he defines alêthia: 'that which is not hidden, not concealed is true' (Foucault 2011, 218), but he adds three more characteristics in his configuration: 'that which is not added to or supplemented, which is not mixed [...] that which is straight [...] that which exists and remains beyond any change' (210). What is important in Foucault's analysis of parrhesia is that all four 'essential values' (219), found in the notion of truth, can be applied both to logos and to praxis or action: 'This notion of truth - as the unconcealed, the unalloyed, the straight, and the unchanging and incorruptible - is applicable [...] to ways of being, ways of doing things, ways of conducting oneself, or forms of action' (219-20).

Living a 'true life' thus becomes the parrhesiastic problem par excellence not just for a line of philosophical lives that Foucault examines and reflects upon, but most importantly for his own life as well. This is where we come full circle with the a posteriori moving moment of Foucault's decision to lecture on the philosopher's death, four months before his own death. Indeed in opening his first lecture at the Collège de France on 1 February 1984, Foucault feels the need to apologise for having delayed the start of his course for a month: ' $\mathrm{J}$ ' ai été malade, réellement malade' [I was ill, really ill] he says. $(2009,3)$ His very last words in closing the course on 28 March 1984 are equally moving: 'Mais enfin, il' est trop tard. Alors merci' [But well, it is too late, so thank you] (309). As noted by Foucault's lifelong partner Daniel Defert, during his medical visits in the last months of his life, Foucault's persistent question seemed to have been: Combien me reste-t-il de temps? [How much time have I got?] (318) As Frédéric Gros therefore notes in his critical evaluation of the last course, Foucault's last lectures have to be read in the light of death, both his own and of Socrates (318).

The premonition of his own death notwithstanding, there were other conditions that had influenced Foucault's preoccupation with questions of truth telling as well as the relationship between philosophy and politics, an issue that had become particularly pertinent in France in 1983 in the wake of the rise of the socialist administration. The French intellectuals had actually been accused of being silent and unwilling to defend the ideas and the deeds of the socialists in power and Foucault alongside Simon de Beauvoir had been particularly pinned down as 'silent intellectuals'. ${ }^{17}$ It is therefore within the specificity of the political conditions in France that Foucault's lectures should also be interpreted and it is no wonder then that Foucault devotes a great part of his lectures to talk about the philosopher's relationship with the prince through reflecting upon the disaster of Plato's involvement in politics at the end of his life. ${ }^{18}$ What emerges as particularly important through Foucault's last lectures is the legacy of changing the interest and object of philosophy altogether from a preoccupation with concepts, notions and arguments to an interest in life practices: 
we can conceive of the idea of a history of philosophy which would be somewhat different from the history traditionally taught today [not] a history of philosophical doctrines, but a history of forms, modes and styles of life, a history of the philosophical life as a philosophical problem. $(2011,210)$

Interestingly enough, Socrates' death, Plato's late involvement in politics and the philosophy/truth/politics assemblage would also preoccupy Arendt's lectures and writings to which I now turn.

3. The pariah as a truth-teller, but how do things change?

The figure of the pariah appears throughout Arendt's work as a courageous truthteller amidst particularly risky situations. In her short essay 'The Jew as pariah' Arendt (1978) actually paints the portrait of four pariah figures: (a) the schlemihl or Lord of Dreams, the people's poet as exemplified by the poetry of Heinrich Heine, (b) the conscious pariah as illuminated by historical figures such as Bernard Lazare, (c) the always suspect and here Charlie Chaplin's cinematic hero comes on stage and (d) the Kafkian hero. All four figures are portrayed as outsiders of their geographies, times and social worlds, but with differentiated attitudes, practices and effects.

'Innocence is the hallmark of the schlemihl' Arendt notes $(1978,70)$, but this comes as no surprise for a poet-pariah, who 'excluded from formal society and with no desire to be embraced within it, turns naturally to that which entertains and delights the common people' (71). Being an outsider of society but at the same time intensely immersed in the beauties and joys of nature, the schlemihl can look at the socialised multitude, criticise them and laugh at them. 'The concept of natural freedom (conceived, be it noted by an outcast able to live beyond the struggle between bondage and tyranny) turns both slaves and tyrants into equally unnatural and therefore ludicrous figures of fun' (73). It is through the force of the schlemihl's creativity that freedom can be visualised. There are strong analogies here with Foucault's preoccupation with the cynic philosopher, as an obscure parrhesiastic figure, whose 'true life' [la vie vraie] is unconcealed, independent, straight and sovereign, master of itself $(2009,231)$. These four aspects of the cynic life are expressed through the cynic philosophers' attachment to nature, their persistent refusal to compromise and their mockery towards all artificialities and pretensions. Still, the schlemihl's remoteness from the world, critical as it is, cannot do much, since 'one has to admit that laughter does not kill and that neither slaves nor tyrants are extinguished by mere amusement' (Arendt 1978, 73).

Given the impasses that the schlemihl - as a poet-pariah can lead to - Arendt turns to the figure of the 'conscious pariah' and the way she attempts to look into the political significance of marginalisation and exclusion. Through political involvement, the conscious pariah thus becomes a rebel; moreover, her agonistic practices brings her in confrontation not only with the forces that marginalise her but also with trends of assimilation and integration, the disappearance of difference and people's right to be different and claim their rights not despite their difference but because of it. Bernard Lazare and his involvement in the Dreyfus Affair is the case study that Arendt draws on in her discussion of the conscious pariah, but elsewhere it is Rahel Varnhagen that appears as a pariah figure whose life and practices Arendt wrote about in her habilitation, her secondary doctoral thesis (Arendt 2000). 
As Sheila Benhabib notes, in writing Varnhagen's life, Arendt traces an existential transition, 'a move away from the psychology of the parvenu to that of the pariah' $(1995,90)$. Indeed, in reading Varnhagen's letters and diaries Arendt could follow narrative traces of the parvenu's transformation from a subject who resists 'fatefulness' by assimilation to an active agent, who 'transforms difference from being a source of weakness and marginality into one of strength and defiance' (Ibid.).

But if 'the conscious pariah' becomes an exemplary rebellious figure for Arendt, why does she feel the need to stage a third figure, the suspect, who comes into life through Chaplin's films? The comic elements of 'the little man's' adventures bring him close to the schlemihl, with the exception that creativity and art are not amongst his options of escaping social order. His world is real, harsh and merciless: breaking the law thus becomes his escapist route but it cannot take him very far. His dealings with the law reveal 'that there is no relation between the offence he commits and the price he pays' (Arendt 1978, 80) and thus expose 'the dangerous incompatibility of general laws with individual misdeeds' (Ibid.). Being portrayed as becoming able to get away with a lot, 'the little man' develops an impudent attitude towards the law, which might become ultimately fatal and self-destructive. And yet, despite his misgivings, Chaplin's pariah also functions as a political figure for Arendt in that his misfortunes and adventures bring people together: they 'recognised in him the image of what society had done to them' (80). By becoming the world's suspect par excellence, Chaplin's hero paves the way for the always, already suspect figure of the refugee, the stateless person, as well as the threats, real and imaginary fears and moral panics that their figure still arises and sustains. Written in 1944, when Arendt herself was a refugee and a stateless person, it is no wonder that sometimes she might have perceived herself and Blücher as figures in Chaplin's movies. Indeed, the day-to-day harsh situations of her life in the beginning of her settlement in New York, with Arendt having to take a two-months placement with an American family, her mother getting piecework from a lace-making factory and Blücher 'shovelling chemicals in a New Jersey factory', evoke such images. ${ }^{19}$

But amongst the four pariah figures of Arendt's essay, it is the Kafkian hero that truly fascinates her. Having experienced the futility of the suspect's innocence or the schlemihl's escapism to either nature or art, the Kafkian pariah's shelter and weapon is thinking: the spaces of contemplation. Indeed, how can one respond to the denunciation that 'you are not of the Castle and you are not of the village, you are nothing at all'? (84) How does it feel to be 'nothing at all', to be denied of your existence? This is what the Kafkian pariah struggles with: the right to enjoy simple things like a home, work, family and citizenship. But 'normal' existence becomes impossible and Kafka's pariah dies from exhaustion in the attempt to insist on the right to have rights. But although real life is a failure, the story of this life enlightens some of the villagers, making them see 'that the rule of the castle is not divine law and, consequently, can be attacked' (88). The villagers' awakening is a positive note in Arendt's essay whose finale is about the necessity of the multitude for the uniqueness of the human existence to be respected and protected:

For only within the framework of a people can a man live as a man among men, without exhausting himself. And only when a people lives and functions in consort with other peoples can it contribute to the establishment upon earth of a commonly conditioned and commonly controlled humanity. (90) 
Written in 1944, just as the news of the concentration camps had started spreading, Arendt's powerful ending opens up a field of political theorising that she went on elaborating till the end of her life. The four pariah figures make multiple and complex contributions in the modalities of truth telling, but they are finally evaluated as politically ineffective, except perhaps from the awareness, meaning and understanding that their stories can enact. It is perhaps not accidental that Arendt decided to abandon philosophy after she fled Germany in 1933, since the idea of the philosopher as pariah seemed to her an impossible project. She talks about it in her interview with Günter Gaus on 28 October 1964, which was broadcasted on West German television:

I always mention that there is a vital tension between philosophy and politics [...] a kind of enmity against all politics in most philosophers [...] Kant is an exception [...]

I want to look at politics, so to speak, with eyes unclouded by philosophy. $(1994,2)$

But of course Jaspers was never persuaded by this statement; he actually wrote fervently against it in a letter sent the day after this interview:

Your farewell to philosophy is a joke [...] It's good that you are instantly punished for making that statement! Your students are demanding philosophy of you and are of course right to do so. You're lecturing on the Critique of Pure Reason now and on Spinoza next Semester. I am happy about that. If you look into all aspects of Spinoza you'll see that he doesn't have the enmity toward politics that you attribute to all philosophers except Kant. I would claim almost the opposite. All of them are very serious about politics [...] except Epicurus [...] and except for the skeptics (not all of them). ${ }^{20}$

As Jaspers succinctly points out above, Arendt's disavowal of philosophy was indeed a joke, or rather a political stance she felt she had to take in publicly accusing the philosophers' silence during the critical years of the rise of Nazism in Germany. It is in this context that she felt the need to celebrate Marxism as a catalytic event in the philosophy/politics troubled history, as already discussed in the first section of the essay. But in reconciling philosophy with politics Arendt's route was via narratives and it is to the relation between narratives, philosophy and politics that I will now turn.

In the last section of her essay 'On the Nature of Totalitarianism', Arendt (1994) juxtaposes solitude as a sine-qua-non condition of philosophical thinking with loneliness as 'a professional danger for philosophers' (1994, 359), a situation where the philosopher 'is deserted even by his own self and lost in the chaos of people (Ibid.). It is because of this 'professional danger', Arendt argues that 'philosophers cannot be trusted with politics' (360); driven ashtray by their will to be left alone, philosophers 'sympathise with tyrannies, where action is not expected of citizens' (Ibid.). As already discussed in the previous section, Arendt's lived experiences as a student of German existential philosophy had given her very good reasons not to trust philosophers. But having reconciled herself with philosophy after her emigration to the States, Arendt revisited and seriously reconsidered her position: 'philosophical truth can become 'practical' and inspire action without violating the rules of the political realm only when it manages to become manifest in the guise of an example', she writes in her essay 'Truth and Politics' $(2006,243)$. There are two important Arendtian theses that derive from this influential essay: (a) 
the force of stories in grounding abstractions and facilitating human communication and the emergence of meaning and (b) the political position of what Liza Disch has denoted as 'situated impartiality': in order to think politically as well as philosophically you need a position from where to speak $(1994,218)$.

Narratives are indeed at the heart of how Arendt conceptualises the political. Drawing on the Aristotelian notion of energeia, her thesis is that 'action as narration and narration as action are the only things that can partake in the most "specifically human" aspects of life' (Kristeva 2011, 41). Not only do stories evade theoretical abstractions, but they reconnect truth and politics by revealing multiple perspectives while remaining open and attentive to the unexpected, the unpredictability and contingency of action, the possibility of change and new beginnings, which is at the heart of what politics is about. In doing so, stories ultimately reconfigure the sphere of politics as an open plane of horizontal connections, wherein the revolution can once again be re-imagined.

Stories for Arendt are thus the only tangible traces of how humans appear to each other and to the world 'through words and deeds' $(1998,198)$ and thus enmesh themselves in the web of human relationships. But as Arendt has noted, 'being seen and being heard by others derive their significance by the fact that everybody sees and hears from a different position' (57). In this light, 'impartiality' or 'objectivity' is always situated in what Arendt calls the 'interspace' or the 'interest': you are always in-the-world-with-others. ${ }^{21}$ But what happens when this 'world that lies between people' (Arendt 1968, 4) disappears? This is the problem that Arendt identifies as crucial in configuring 'dark times' as a regime wherein 'the public realm has lost the power of illumination' (Ibid.). Arendt's position here is that when living in dark times human beings need to take up a position of 'vigilant partiality' (29). Having posited the argument that academic education is entering a regime of 'dark times' in the beginning of this essay, what I want to do in its last section is to create a plane of consistency wherein parrhesia as an assemblage of practices of truth telling, the figure of 'the conscious pariah' and the situated position of vigilant partiality create conditions of possibility for following Arendt's crucial suggestion in the Human Condition: 'What I propose, therefore, is very simple: it is nothing more than to think what we are doing' $(1998,5)$.

\section{Academics in dark times}

Following Arendt, one could indeed argue that we currently live through 'dark times' and there is already ample abundance of evidence, as well as a growing body of scholarship. ${ }^{22}$ Ball's 1995 essay 'Intellectual or technicians: The urgent role of theory in educational studies' has been an important early intervention in this area of problematisation and thinking. Ball's main argument was that we needed to shift away from 'a technical rationalist approach' $(1995,255)$ and try instead to employ theory so as to become once more able to see clearly and in an Arendtian mode to 'think what we are doing'. What Ball was suggesting back in 1995 was that 'educational studies is in a sorry state, and in danger of becoming sorrier' (256), but I have a feeling that he had not imagined back then how 'sorrier' the situation would actually become within and beyond educational studies. The role of the academic as an intellectual was of course at the heart of Ball's argument, while 'intellectual isolationism' (256) had been identified as a symptom of the problem with educational studies. ${ }^{23}$ 
But what is the role of the academic in dark times? And what types of politics can develop as a response to this? As already discussed in the second section, parrhesia is entangled in a network of power relations wherein the freedom to tell the truth is interwoven with the risk of being exposed to 'the powerful other'. As Stivers $(2004,21)$ has aptly put it, 'the validity of fearless speech is established by its riskiness'. But how can 'the powerful other' be configured within the space of academia, how exactly can we map the risks involved in the parrhesiastic game and finally what are the conditions of possibility for parrhesia in the era of 'the cuts'?

As already discussed in the first section, for both Foucault and Arendt, truth as a Heideggerian notion is about unconcealment, uncovering and in this light the politics of truth is not about establishing valid knowledges, but rather about understanding complex configurations and truth games through which practices and discourses are scientifically validated and become dominant. The quest for meaning and understanding is therefore a process of uncovering the veil that both covers and hides the material conditions and fierce power relations at play through which 'dominant truths' and master narratives' are constituted and established. In this light, fearless speech is about the courage to take up a situated position and simply dare say: 'the emperor has no clothes'.

There are indeed many instances in the increasing bureaucratisation and marketisation of academic life that the parrhesiastic role of the academic would be to reiterate the statement that there is less and less meaning and essence in what we say, write and do in our everyday lives. As a matter of fact, academics have been very good at reflecting upon, analysing and writing about academic performativity, audit cultures and the panopticisation of the academy. ${ }^{24} \mathrm{We}$ are not short of analyses or theories; what we are short of is action, the mere gesture of reiteraring Bartleby's simple response: 'I would rather not'. ${ }^{25}$

This lack of doing something other than writing, is of course an effect of the globalised aspect of a phenomenon, which is part and parcel of the neoliberalism agenda, but there is more to it. As it has been pointed out and discussed, audit cultures are not straightforward systems of domination, but rather matrices of complex practices, values and discourses, 'at once obstructive and enabling' (Strathern 2000). Moreover academic performativity is both a regime of terror as influentially analysed by Ball, ${ }^{26}$ but also a psychosocial milieu of what has been discussed as 'academic narcissism'. 27

Performativity and audit cultures in the academy are thus entangled components within larger 'assemblages of power and desire' (Tamboukou 2010). It is I argue in the receding and erasure of the need for and memory of action that we are entering a milieu of 'dark times'. Academic 'resistance' is translated into withdrawal from public academic spaces into archives, libraries and private studies: we opt to hide from the world and from each other, gradually unravelling the Arendtian web of human relations, which illuminates our 'deeds and words' and holds us together. This withdrawal does not initially seem to be harmful for academics as individuals; sometimes, it can even appear as beneficial for the intellectual who withdraws from the world and develops her genius and talent in writing sophisticated books and articles or successful grant applications. 'But with each such retreat', Arendt reminds us $(1968,4)$ 'an almost demonstrable loss to the world takes place; what is lost is the specific and usually irreplaceable in-between'. There is a need to think carefully about the specificities as well as effects of losing this Arendtian 'inbetween', within the spaces of the university today. 
What is also important to recognise here is that in terms of the material and discursive conditions of the parrhesiastic game within academia, we are part of 'the powerful other' we want to challenge and in this context the Bartlebian response, 'I would rather not', is not simply addressed to some superior hierarchies - although in many cases it does - but also to our peers and friends as well as to ourselves. We constantly need to reiterate it, but also listen to it. Parrhesia is not just about having the courage to tell the truth, but also to listen to it carefully, even if this means that we will have to inhabit the position of 'the conscious pariah'. Truth is that academics as intellectuals have actually been marginalised and even erased from the language and the grammar of higher education policy documents (see Sabri 2010). In this context, more and more academics are currently inhabiting the three Arendtian pariah positions as configured and discussed above: academic escapism, as I want to call it, has indeed become a route many of us have taken up as a survival tactic. But we need to remember here that 'laughter does not kill' (Arendt 1978, 73) and that mere defiance cannot make things change. Here, the figure of Socrates as a philosopher/teacher becomes crucial. Socrates' parrhesia reminds us that by hiding from the world we fail in our responsibility as teachers to inspire young people in the quest for freedom, a problem that Blücher had raised in the beginning of this essay. Although fearless speech is open to everyone, academics as teachers and pedagogues, have assumed extra responsibilities in sustaining the web of human relations and opening up potential sites where students can be educated in telling the truth as they see it, but also in listening to others.

Here also comes that Kantian approach to the effects of seeing, remembering and imagining the revolution, that both Foucault and Arendt have referred to in their reflections on the relation between truth and politics as discussed in the first section above. Kant's main argument was that the event of the French revolution should not be evaluated in terms of its immediate effects, or its possible success or failure, but rather in terms of its aura in enacting memories of revolt and hopes for a different future. As he was writing in a most clairvoyant way:

The revolution, which we have seen taking place in our own times $[\ldots]$ may succeed or may fail [...] a phenomenon of this kind which has taken place in human history can never be forgotten [...] For the occurrence in question is too momentous, too intimately interwoven with the interests of humans and too widespread in its influence upon all parts of the world for nations not to be reminded of it when favourable circumstances present themselves, and to rise up and make renewed attempts of the same kind as before. (Kant 2011, 182, 184, 185)

In writing about the revolution as an onlooker who had been irrevocably affected by its occurrence, Kant was finally flagging up the role of the philosopher as an enlightener, her duty being to 'instruct people upon their duties and rights towards the state' $(2011,186)$. Such instructors can only be 'free teachers of right, i.e. the philosophers. The latter, on account of the very freedom, which they allow themselves, are a stumbling-block to the state, whose only wish is to rule' (Ibid.). Philosophers as teachers are thus entitled to enlighten people in freedom through 'the freedom, which they allow themselves', a Kantian point which reverberates with how Foucault highlights the importance of the link between logos and bios, discourse and life in the philosopher's parrhesia, but also with Arendt's configuration of 'the conscious pariah' and her position of 'vigilant partiality' in acting and speaking. In this light, the parrhesiastic game within the academia is more complex 
in terms of the difficulty of pinning down 'the powerful other', but also in terms of the risks involved, including the failure of becoming 'a stumbling-block to the state', and therefore an instructor of freedom, a point that brings the discussion full circle to Blücher's question as posed in the beginning of this essay.

\subsection{Academic spaces and the enactment of politics}

In this essay, I have considered the problem of truth telling through the notion of parrhesia as developed and explicated in Foucault's last lectures at the College de France (1982-1983 and 1983-1984) and the figure of the conscious pariah that runs throughout Arendt's work (1978). In tracing connections and tensions in the way the two thinkers explore questions and dilemmas around the courage to tell the truth in philosophy and politics, I have expressed the fear that academics in the UK have entered an era of 'dark times': as we gradually withdraw from practices of acting and speaking together, conditios sine-qua-non of the political in Arendt's thought, we also fail in our task as teachers to inspire our students in the pursuit of freedom. In raising the need for the importance and urgency of action, what I finally suggest is that maybe, this is again 'a time of struggle between two ways of thinking: thinking evasively and thinking to the point ... a time of conflict between theory that plays fast and loose with practice and theory that learns from practice' (Havel 1992, cited in Stivers 2004, 23).

\section{Notes}

1. Blücher to Jaspers, 5 September 1961 in Arendt-Jaspers $(1993,451)$.

2. Arendt met Blücher (1899-1970) in Paris; they were both exiled and stateless Germans fleeing Nazism. They got married in Paris, shortly before they fled together to New York in 1941. Blücher took several manual jobs as a non-speaking English immigrant in New York, before he started teaching at the New English School for Social Research and later at Bard College in the 1950s. Apart from some reviews, he never published but after his death Arendt arranged for his lectures at Bard to be transcribed with a publication project in mind. Arendt died unexpectedly in 1975 and Blücher's lectures were never published, but they can be accessed today at the Blücher Archive at Bard College: http:// www.bard.edu/bluecher/lectures/index.htm.

3. Ibid., 452.

4. Villa (1992) has considered affinities and tensions between Foucault's conceptualisation of power and the Arendtian configuration of the public sphere; Tully (1999) has considered Foucault and Arendt alongside Wittgestein and Skinner in reconsidering citizenship, freedom and democratic participatory politics; Allen (2002) has traced affinities in Foucault's and Arendt's theorisation of power, agency and subjectivity, arguing in particular that the two thinkers' different take on power is complementary rather than oppositional in the constitution of subjectivity and agency and Stivers (2004) has drawn connections between Arendt's notion of 'vigilant partiality' and the Foucauldian notion of parrhesia, while Braun (2007) has explored correlations between temporality in Arendt and modern biopolitics in Foucault.

5. I refer here of course to Heidegger's political behaviour and particularly his brief endorsement of Nazism in 1933, which Arendt herself has publicly criticised (1994, 187, n. 2), despite her later generosity in forgetting and forgiving. For the ArendtHeidegger relationship see Arendt and Heidegger (2004), Ettinger (1995) and MaierKatkin (2010).

6. Arendt to Heidegger, 28 October 1960, not sent, Hannah Arendt Literary Trust.

7. For an overview of Heidegger's influence on Foucault, see amongst others, Milchman and Rosenberg (2003) and Elden (2001). See also Hinchman and Hinchman (1984) for an excellent discussion of Heidegger's influence on Arendt's thought. 
8. Foucault's complimentary thesis was submitted to the University of Paris, Sorbonne in 1961 and published in 1964, but was only translated in English in 2007 (Foucault 2007).

9. See Foucault (2010, 6-39), see also Foucault (1984).

10. The essay 'What is Enlightenment' was written in September 1784 and was published in December in the German journal Berlinische Monatschrift. All three Kant's essays that Foucault discusses are included in Reiss' edited collection of Kant's Political Writings (2011).

11. In her posthumously published Lectures on Kant's Political Philosophy, first given at the New School for Social Research in the 1970 Fall semester, Arendt discusses at length Kant's views on the French Revolution, particularly referring to Kant's The Contest of the Faculties (Part II, Sections 6 and 7) and Perpetual Peace (Appendix II). See Arendt (1982, sessions, 7-11, 40-68).

12. For a detailed discussion of the etymology and a literary genealogy of parrhesia, see Foucault (2011).

13. In the mythic plot of the play, Kreusa, daughter of the king of Athens Erectheus was seduced or raped by Apollo when she was a young girl; she gave birth secretly and abandoned the infant. Under the orders of Apollo, Hermes rescued Ion and safely carried him to Delphi to grow up in the holly atmosphere of the temple. Later in life Kreusa visits the temple with her husband Xouthos, who is a foreigner in Athens, albeit king of the city through his marriage with the princess. The royal couple wants to know whether they will ever have a child and Apollo's answer to Xouthos is that he already has one, the first man he will meet on leaving the oracle and of course this man turns out to be Ion. After certain misunderstandings Xouthos presents himself to Ion as his father and asks him to go to Athens with him and eventually become his heir. Ion hesitates: how can he rule a city, if he is a foreigner? He needs to know who his mother is.

14. See Foucault (2011), end of lecture four till lecture eight (61-147). The notion of parrhesia was also the theme of six lectures at Berkeley in the fall of 1983, given as part of Foucault's seminar 'Discourse and Truth' (Foucault 2001).

15. These four modalities of truth-telling and their corresponding figures are discussed in the very first lecture of the 1984 course $(2011,1-31)$.

16. As Thomas Flynn has noted, the four roles in truth-telling can coexist or overlap in one person, they are not mutually exclusive $(1991,104)$.

17. See Gros' commentary on these debates in contextualizing the 1982-1983 course (Foucault 2010, 390, n. 39).

18. See Foucault (2010), Lectures on 12 January, 9 February, particularly the section on Plato's political autobiography, (2010, 212-9) and 23 February 1984.

19. See Young-Bruehl (1982), particularly Chapter 5, 164-73.

20. Jaspers to Arendt, 19 October 1964 (Arendt-Jaspers 1993, 572).

21. For references to the 'interesse' in Arendt's work, see inter alia, the Human Condition $(1998,182)$ and Men in Dark Times $(1968,31)$.

22. See amongst others Strathern (2000), Morley (2003), Olssen and Peters (2005), Archer (2008), Ball and Exley (2010), Holmwood (2011) and Peters (2011).

23. The role of the intellectual has of course a genealogy of its own, which goes back to Plato, but its exploration goes beyond the limits of this essay.

24. See amongst others, Ball (2006) and Unterhalter and Carpentier (2010).

25. I refer here of course to Herman Melville's well-known story: Bartleby the Scrivener: A Story of Wall Street.

26. See Ball (2006) for an overview of his overall work on academic performativity.

27. See Matthew Reisz's article 'Whither Art: Vanity is killing social sciences and the Humanities' in Times Higher Education, 29 October 2009. See also Rustin and Rustin (2010).

\section{Notes on contributor}

Maria Tamboukou (BA, MA and $\mathrm{PhD}$ ) is a professor of feminist studies and co-director of the Centre of Narrative Research, at the University of East London. Her research interests and publications are in auto/biographical narratives, feminist theories, Foucauldian and Deleuzian analytics, the sociology of gender and education, gender and space and the 
sociology of art. Recent publications include the monographs In the Fold Between Power and Desire: Women Artists' Narratives; Nomadic Narratives: Gwen John's Letters and Paintings; Visual Lives: Carrington's Letters, Drawings and Paintings and the co-edited collections: Doing Narrative Research and Beyond Narrative Coherence. She is currently working on a genealogy of the seamstress, a British Academy funded project, looking into auto/biographical narratives of home-based dressmakers and women working in the garment industry.

\section{References}

Allen, A. 2002. Power, subjectivity and agency: Between Arendt and Foucault. International Journal of Philosophical Studies 10, no. 2: 131-49.

Archer, L. 2008. Younger academics' constructions of 'authenticity', 'success' and professional identity. Studies in Higher Education 33, no. 4: 385-403.

Arendt, H. 1968. Men in dark times [1955]. New York, NY: Harvest Books.

Arendt, H. 1978. The Jew as pariah. ed. R.H. Feldman. New York, NY: Grove Press.

Arendt, H. 1981. The life of the mind. ed. M. McCarthy. New York, NY: Harcourt.

Arendt, H. 1982. Lectures on Kant's political philosophy. ed. R. Beiner. Brighton: The Harvester Press.

Arendt, H. 1994. Essays in understanding 1930-1954: Formation, exile and totalitarianism. ed. J. Kohn. New York, NY: Schocken Books.

Arendt, H. 1998. The human condition [1958]. Chicago, IL: University of Chicago Press.

Arendt, H. 2000. Rahel Varnhagen: The life of a Jewess [1957]. Trans. R. Winston, C. Winston and ed. L. Weissberg. Baltimore, MD: The Johns Hopkins University Press.

Arendt, H. 2006. Between past and future: Eight exercises in political thought [1961]. London: Penguin Books.

Arendt H., and Heidegger M. 2004. Letters, 1925-1976. Trans. A. Shields and ed. U. Ludz. New York, NY: Harcourt Brace.

Arendt, H., and Jaspers K. 1993. Correspondence, 1926-1969. Trans. R. Kimber, R. Kimber and eds. L. Köhler, H. Saner. New York, NY: Harcourt Brace.

Ball, S.J. 1995. Intellectuals or technicians? The urgent role of theory in educational studies, British Journal of Educational Studies 43, no. 3: 255-71.

Ball, S.J. 2006. Education policy and social class. The selected works of Stephen J. Ball. London: Routledge.

Ball, S.J., and S. Exley. 2010. Making policy with 'good ideas': Policy networks and the 'intellectuals' of New Labour. Journal of Education Policy 25, no. 2: 151-69.

Benhabib, S. 1995. Hannah Arendt and the redemptive power of narrative. In Hannah Arendt: Critical essays, ed. L. Hinchman and S. Hinchman, 111-41. New York, NY: State University of New York Press.

Braun, K. 2007. Biopolitics and temporality in Arendt and Foucault. Time and Society 16, no. 1: 5-23.

Disch, L.J. 1994. Hannah Arendt and the limits of philosophy. Ithaca, NY: Cornell University Press.

Elden, S. 2001. Mapping the present: Heidegger, Foucault and the project of a spatial history. London: Continuum.

Ettinger, E. 1995. Hannah Arendt and Martin Heidegger. New Haven, CT: Yale University Press.

Flynn, T. 1991. Foucault as parrhesiast: His last course at the Collège de France. In The final Foucault, ed. J. Bernauer and D. Rasmussen, 102-18. Cambridge: MIT Press.

Foucault, M. 1984. What is enlightenment? In The Foucault reader, ed. P. Rabinow, Trans. C. Porter, 32-50. London: Penguin.

Foucault, M. 1988. Truth, power, self: An interview with Michel Foucault. In Technologies of the self, ed. L. Martin, H. Gutman, and P. Hutton, 9-15. London: Tavistock.

Foucault, M. 1990. The return of morality. Interview by Gilles Barbadette and André Scala. In Michel Foucault, Politics philosophy, culture, ed. Laurence, D. Kritzman, Trans. T. Levin and I. Lorenz, 242-267. London: Routledge.

Foucault, M. 2001. Fearless speech. ed. Joseph Pearson. Los Angeles, CA: Semiotext(e). 
Foucault, M. 2007. Introduction to Kant's anthropology. Trans. R. Nigro, K. Briggs and ed. R. Nigro. Los Angeles, CA: Semiotext(e).

Foucault, M. 2008. Le Gouvernement de Soi et des Autres: Cours au Collège de France 1982-1983 [The government of self and others: Lectures at the Collège de France 19821983]. Paris: Gallimard.

Foucault, M. 2009. Le Courage de la Vérité, Le Gouvernement de Soi et des Autres II: Cours au Collège de France 1983-1984 [The courage of truth, the government of self and others II: Courses at the college de France, 1983-1984]. Paris: Gallimard.

Foucault, M. 2010. The government of self and others: Lectures at the Collège de France 1982-1983. Trans. G. Burchell. Basingstoke: Palgrave.

Foucault, M. 2011. The courage of truth: Lectures at the Collège de France II. 1983-1984. Trans. G. Burchell. Basingstoke: Palgrave.

Heidegger, M. 1998. On the essence of truth [1943/1930]. In Martin Heidegger - pathmarks, ed. W. McNeill, Trans. J. Sallis, 136-54. Cambridge: Cambridge University Press.

Heidegger, M. 2002. The essence of truth: On Plato's parable of the cave allegory and Theatetus. Trans. T. Sadler. London: Continuum.

Hinchman, L., and S. Hinchman. 1984. In Heidegger's shadow: Hannah Arendt's phenomenological humanism. Review of Politics 46, no. 2: 183-211.

Holmwood, J. 2011. A manifesto for the public university. London: Bloomsbury Academic.

Jaspers, K. 1961. The idea of the university. London: Peter Owen.

Kant, I. 1952. The critique of judgement. Trans. J.C. Meredith. New York, NY: Oxford University Press.

Kant, I. 2011. The contest of faculties. In Kant, political writings, ed. H.S. Reiss, Trans. H.B. Nisbet. Cambridge: Cambridge University Press.

Kristeva, J. 2011. Hannah Arendt. Trans. R. Guberman. New York, NY: Columbia University Press.

Maier-Katkin, D. 2010. Stranger from abroad: Hannah Arendt, Martin Heidegger, friendship and forgiveness. New York, NY: W.W. Norton.

Milchman, A., and A. Rosenberg, eds. 2003. Foucault and Heidegger: Critical encounters. Minneapolis, MN: University of Minnesota Press.

Morley, L. 2003. Quality and power in higher education. Berkshire: Open University Press.

Olssen, M., and M.A. Peters. 2005. Neoliberalism, higher education and the knowledge economy: From the free market to knowledge capitalism. Journal of Education Policy 20, no. 3: 313-45.

Peters, M.A. 2011. Neoliberalism and after? Education, social policy, and the crisis of western capitalism. New York, NY: Peter Lang.

Reiss, H.S., ed. 2011. Kant: Political writings. Trans. H.B. Nisbet. Cambridge: Cambridge University Press.

Rustin, M., and M. Rustin. 2010. States of necicism. In Enduring loss: Mourning, depression and narcissism throughout the life cycle, ed. E. McGinley and A. Varchevker, 20934. London: Karnac.

Sabri, D. 2010. Absence of the academic from higher education policy. Journal of Education Policy 25, no. 2: 191-205.

Strathern, M., ed. 2000. Audit cultures: Anthropological studies in accountability, ethics and the academy. London: Routledge.

Stivers, C. 2004. On theorizing in dark times. Administration Theory and Praxis 26, no. 9: $19-26$.

Tamboukou, M. 2010. In the fold between power and desire: Women artists' narratives. Newcastle-upon-Tyne: Cambridge Scholars.

Tully, J. 1999. The agonic freedom of citizens. Economy and Society 28, no. 2: 161-82.

Unterhalter, E., and V. Carpentier, eds. 2010. Global inequalities and higher education: Whose interests are we serving? Basingstoke: Palgrave.

Villa, R.D. 1992. Postmodernism and the public sphere. The American Political Science Review 86, no. 3: 712-21.

Young-Bruehl, E. 1982. Hannah Arendt: For love of the world. New Haven, CT: Yale University Press. 